\title{
Editorial
}

Z Gerontol Geriat 2015 • 48:503-504

DOI 10.1007/s00391-015-0936-6

Published online: 5 August 2015

๑) Springer-Verlag Berlin Heidelberg 2015

\author{
Manfred Gogol ${ }^{1}$. Andreas Simm ${ }^{2}$ \\ ${ }^{1}$ Klinik für Geriatrie, Krankenhaus Lindenbrunn, Coppenbrügge, Germany \\ ${ }^{2}$ Heart Centre of the University Hospital Halle (Saale), Martin-Luther \\ University Halle-Wittenberg, Halle (Saale), Germany
}

\section{Stress: the good, the bad and the ugly?}

fore, the idea arises to look at an important topic like stress from different areas of gerontology.

In the first paper "Stress and biological aging: a double-edged sword" Simm and Klotz address the biological knowledge of what happens regarding stress and ageing in living systems. The main message is that stress, such as oxidative stress happens during the whole life course, is biological inevitable, and is followed by adaptation in different aspects $[3,4]$. For example, advanced glycation endproducts (AGE) as a biomarker of ageing are within our daily nutrition but for example also linked to outcome in coronary artery bypass patients [5]. The second main point is that stress even contributes to the ageing process - and therefore to the development of (chronic) diseases and functional decline - by the stress exposure itself over time and a declining capacity of repair mechanisms. Furthermore, they mention the fact that stress exposure is not in general bad and adaptation can also lead to a positive outcome [6]. In this way, stress is essential and a prerequisite for adaptation, prevention and further development.

In the second paper by Wanka et al. stress was analyzed from a social viewpoint based on "well-being", a quantitative online survey in four countries. The baby boomer generation, born between World War II and 1970, was thought to have faced a lot of stressors. Indeed, employees of the baby boomer generation express to a high percentage symptoms of physical and psychological stress. Whereas social support positively influences the negative effects of a limited health and lower education for female baby boomers, male baby boomers lack the resources to effective- ly cope with work strains. It is of note that the progress in measuring biomarkers in disease and ageing more and more reveals also the link between social stress and biology as it's shown in children $[7,8]$.

In the field of old age psychology the high diversity in stress reactions was shown in disease, e.g. myocardial infarction [9], emotional stress like depression [10], and bereavement [11]. Interestingly, in the third paper, Schilling and Diehl focus on affective reactivity to daily stressors especially in old age. They concentrate on two main postulations: firstly, ageing should be associated with increased affective reactivity and secondly, due to adapted emotional self-regulation skills during the life span, there should be an age-related decrease in stress reactivity. As the results regarding both these facts are inconsistent, the main message of this paper is that older adults react to multiple stressors in a more adaptive way than younger adults. The capacity in highly vulnerable elderly people exposed to posttraumatic stress depends of many factors [12]. It is fascinating that it was now shown that psychotherapeutic interventions in posttraumatic stress disorder patients may reduce the amount of basal DNA breakage [13].

The last paper "Stress and optimal ageing" by Gogol makes the effort to combine knowledge from biology and medicine. As many of the basic hallmarks of ageing are now measurable on cellular and organ levels, he points out that a life course approach to chronic disease today in medicine is missing but in progress. The accumulation of stress during lifetime and the age-associated development of chronic diseases raises some questions. Firstly, is it pos- 
sible to disentangle ageing from disease, and secondly, is the term "healthy ageing" the right one? As there is a growing body of evidence about successful interventions in the elderly population - even in high age - questions remain about our biological understanding and the right interventions in a highly diverse population. Most research now is done in the field of cardiovascular disease $[14,15]$ and nutrition [16, 17] or both [18] linking basic mechanisms with disease and interventions $[18,19]$. That means also to define elderly people as a minority - such as sex and gender and ethnicity - in clinical research [20].

Within the framework of suspense focusing on stress from biology to social and psychological science up to the integrative concept of medicine, it can clearly be seen that stress is not a simple and easy concept. Historically, in a biological context, factors/demands causing a disturbance of the homeostasis can be experienced as stress. Regarding the different views on stress, wording as well as conceptual research changes within the different disciplines. At the end, as all of them will affect human health, we have to integrate these different lines of research [21].

\section{Corresponding address}

\section{Dr. M. Gogol}

Klinik für Geriatrie

Krankenhaus Lindenbrunn

Lindenbrunn 1

31863 Coppenbrügge

gogol@krankenhaus-lindenbrunn.de

\section{Prof. A. Simm}

Heart Centre of the University

Hospital Halle (Saale)

Martin-Luther University Halle-Wittenberg

Ernst-Grube Str. 40

06120 Halle (Saale)

andreas.simm@uk-halle.de

Conflict of interest. M. Gogol and A. Simm declare there are no conflicts of interest.

\section{References}

1. Künemund H, Schroeter KR (2015) GerontologieMulti-, Inter- und Transdisziplinarität in Theorie und Praxis. Z Gerontol Geriatr 48:215-218

2. Brandenburg $H$ (2015) Interdisziplinarität in der Gerontologie. Z Gerontol Geriatr 48:220-224
3. Morimoto Rl, Cuervo AM (2014) Proteostasis and the aging proteome in health and disease. $J$ Gerontol A Biol Sci Med Sci 69:S33-S38

4. Zapata HJ, Quagliarello VJ (2015) The microbiota and microbiome in aging: potential implications in health and age-related diseases. J Am Geriatr Soc 63:776-781

5. Simm A, Philipp C, Friedrich MD et al (2014) Intraoperative sRAGE kinetics. Z Gerontol Geriatr 47:666-672

6. Guo H, Callaway JB, Ting JP-Y (2015) Inflammasomes: mechanism of action, role in disease, and therapeutics. Nat Med. doi:10.1038/nm.3893 (June 29, 2015)

7. Johnson DE, Guthrie D, Smyke AT et al (2010) Growth and associations between auxology, caregiving environment, and cognition in socially deprived Romanian children randomized to foster vs ongoing institutional care. Arch Pediatr Adolesc Med 164:507-516

8. Mitchell C, Hobcraft J, McLanahan SS et al (2014) Social disadvantage, genetic sensitivity, and children's telomere length. Proc Natl Acad Sci USA 111:5944-5949

9. Xu X, Bao H, Strait Ket al (2015) Sex differences in perceived stress and early discovery in young and middle-aged patients with acute myocardial infarction. Circulation 131:614-623

10. Cai N, Chang S, LiY et al (2015) Molecular signatures of major depression. Curr Biol 25:1-11

11. Richardson VE, Bennett KM, Carr D et al (2015) How does bereavement get under the skin? The effects of late-life spousal loss on cortisol levels. J Gerontol B Psychol Sci Soc Sci 70:341-347

12. Noll-Hussong M (2014) Neurobiologie posttraumatischer und somatoformer Störungen im Alter. Z Gerontol Geriatr 47:209-213

13. Morath J, Moreno-Villanueva M, Hamuni G et al (2014) Effects of psychotherapy on DNA strand break accumulation originating from traumatic stress. Psychother Psychosom 83:289-297

14. Andersen MM, Kritchevsky SB, Morgan TM et al (2015) Increased cardiovascular stiffness and impaired age-related functional status. J Gerontol A Biol Sci Med Sci 70:545-553

15. Bäck M, Hansson GK (2015) Anti-inflammatory therapies for atherosclerosis. Nat Rev Cardiol 12:199-211

16. Mitchell SJ, Martin-Montalvo A, Mercken EM et al (2014) The SIRT1 activator SRT 1720 extends lifespan and improves health of mice fed a standard diet. Cell Reports 6:836-843

17. Brandhorst S, Choi IY, Wei M et al (2015) A periodic diet that mimics fasting promotes multi-system regeneration, enhanced cognitive performance, and healthspan. Cell Metabolism. doi:10.1016/j. cmet.2015.05.012 (June 18, 2015)

18. Kokkinos PF, Faselis C, Myers J et al (2013) Interactive effects of fitness and statin treatment on mortality risk in veterans with dyslipidaemia: a cohort study. Lancet 381:394-399

19. Savela S, Saijonmaa O, Strandberg TE et al (2013) Physical activity in midlife and telomere length measured in old age. Experiment Geront 48:81-84

20. Jové M, Maté I, Naudi A et al (2015) Human aging is a metabolome-related matter of gender. J Gerontol A Biol Sci Med Sci. doi:10.1093/gerona/ glv074 (May 26, 2015)

21. High KP (2013) Infrastructure and resources for an ageing population: embracing complexity in translational research. Translat Res 163:446-455

\section{Zwei neue Patienteninforma- tionsbroschüren der BZgA zum Thema Sturzprävention}

Unter dem Dach des Programms "Gesund und aktiv älter werden" entwickelt die Bundeszentrale für gesundheitliche Aufklärung (BZgA) gegenwärtig das Präventionsprogramm "Älter werden in Balance". Zielsetzung des Programms ist es, durch körperliche Aktivität und Bewegung die Gesundheit und Lebensqualität älterer Menschen in Deutschland zu fördern, Pflegebedürftigkeit so weit wie möglich hinauszuschieben und eine wachsende Sensibilisierung für das Thema Gesundheit im Alter herzustellen.

Im Rahmen dieses Programmes haben die Bundesinitiative Sturzprävention und die BZgA zwei Broschüren entwickelt. Anfang Juli 2015 wurde die Broschüren mit großer Resonanz erstmals auf dem 11. Deutschen Seniorentag in Frankfurt a.M. vorgestellt.

Broschüre 1: „Gleichgewicht und Kraft - Einführung in die Sturzprävention"

Broschüre 2: ,Gleichgewicht und Kraft - das Übungsprogramm".

Neben einem Trainingsprogramm werden Informationen zu dem wichtigen Thema dargestellt. Verständlich erklärt, liefern sie Tipps, Hilfen, nützliche Adressen und Anleitung wie Stand- und Gangsicherheit verbessert werden können. Dabei wird sehr genau darauf geachtet, dass nur bewährte Maßnahmen und Übungen weiterempfohlen werden. Die Idee für die Broschüre stammt aus England (AgeUK) und wurde im EU Netzwerk ProFouND (Prevention of Falls Network for Dissemination) weiterentwickelt. Zielgruppen sind besonders geriatrische Patienten und deren Familien, die entweder sturzgefährdet sind oder einen Sturz hatten. Die Koordination der Inhalte lag bei Dr. Niki Brenner und Prof. Clemens Becker, Robert-Bosch-Krankenhaus, Stuttgart.

Zu beziehen sind beide Broschüren als kostenloses PDF-Dokument zum downloaden oder auf Bestellung über die Webseite www.bzga.de unter der Rubrik Infomaterialien "Gesundheit älterer Menschen" oder per Post: BZgA Bundeszentrale für gesundheitliche Aufklärung, 50819 Köln. 